\title{
The Effectiveness of Birth Ball During Pregnancy in Length of Labor
}

\author{
1st Siti Mutoharoh \\ Midwife Diploma Study Program \\ Muhammadiyah Health Sciences \\ Institute of Gombong \\ Gombong, Indonesia \\ Sitimutoharoh23@gmail.com
}

\author{
2nd Kusumastuti \\ Midwife Diploma Study Program \\ Muhammadiyah Health Sciences \\ Institute of Gombong \\ Gombong, Indonesia \\ ncuz.kusuma26@gmail.com
}

\author{
3rd Eni Indriyani \\ Midwife Diploma Study Program \\ Muhammadiyah Health Sciences \\ Institute of Gombong \\ Gombong, Indonesia \\ eni.indryani29@gmail.com
}

\begin{abstract}
The number of dead in Indonesia in 2015 reached a high rate, were 305 per 100,000 live births. Maternal deaths that occur in Indonesia are caused by several factors, including long-standing or obstructed labour by $5 \%$. Birth ball is a physical therapy ball that helps with labour and can be used in various positions. One of the exercises in birth ball is to sit on the ball by wiggling your pelvis and is considered to be able to provide comfort and speed up labour. The sitting position above the birth ball, is assumed to be similar to squatting open the pelvis so that it helps accelerate labour. The research method used was a quasiexperimental in two groups, namely the treatment group and the control group with 30 respondents each. Respondents in this study were physiologically pregnant women with a gestational age of more than 34 weeks. The results showed there were differences in the length of labour between the treatment group and the control group. The difference in duration of first stage of labour between the treatment group and the control group is shown by the p-value of 0.002 and RR 1.36. While the difference in the second-stage length in the treatment group compared with the control group is indicated by the p-value of 0.020 and RR 1.33. The conclusion of the study is that there was a significant difference in the length of labour in the first and second stages between the treatment group given birth ball exercises and the control group.
\end{abstract}

\section{Keywords: birth ball, pregnancy, length of labor}

\section{INTRODUCTION}

The number of dead in Indonesia in 2015 is still high, namely 305 per 100,000 live births [1]. Maternal deaths that occur in Indonesia are caused by several factors, it is evident that old parturition or parturition is jammed by $5 \%$. Particles that last more than 18 hours will cause the mother to become infected, dehydrated, and increase, increasing the risk of death for the mother [2].
The birth ball is a physical therapy ball that helps with labor and can be used in various positions. One of the movements of a birth ball exercise consists of sitting on the ball by wiggling the pelvis, providing comfort and accelerating labor [3].

The use of birth ball during pregnancy will stimulate postural reflexes and maintain the muscles that support the spine. The sitting position on the ball, is assumed to be similar to squatting open the pelvis so that it helps accelerate labor. If the ball is placed on the bed, then do the exercises in a kneeling position or bending with weight resting on the ball, moving to push the pelvis then the baby will change to the correct position. This activity will be useful in shortening maternity time [4].

Research conducted by Mirzakhani, et al (2014) [5] states that there is a significant relationship between the groups treated with birth ball training during pregnancy to the duration of labor because it can reduce pain at the opening, accelerate cervical dilatation and facilitate labor.

The birth ball exercise has several exercises movements, including Pelvic Rocking Exercises. The results of Surtiningsih, et al. (2016) [6] showed that there were differences in the length of time the first stage of labor in primiparous mothers who did Pelvic Rocking Exercises and those who did not do Pelvic Rocking Exercises with $\rho$-values of $0,0001<\alpha(0.05)$.

The purpose of this study was to identify pregnant women and find out the effectiveness of birth ball exercise on labor.

\section{METHOD}

This research was a quasi-experimental quantitative research in two groups, namely the treatment group and the control group with 30 respondents each. Data analysis using chi-square. Respondents in this study were physiologically pregnant women with a gestational age more than 34 weeks. The treatment group performed birth ball exercises 4 times in 4 weeks.

\section{RESULT AND DISCUSSION}

1. The characteristic of respondents

Table 1. The distribution of respondent's characteristic frequencies 


\begin{tabular}{|c|c|c|c|c|c|}
\hline No. & Characteristic & \multicolumn{2}{|c|}{ Treatment } & \multicolumn{2}{|c|}{ Control } \\
\hline & & $\mathrm{n}$ & $\%$ & $\mathrm{n}$ & $\%$ \\
\hline \multirow[t]{2}{*}{1} & Age & & & & \\
\hline & $<20$ and $>35$ & 8 & 26.7 & 9 & 30.0 \\
\hline \multirow{4}{*}{2} & $20-35$ & 21 & 73.3 & 22 & 70.0 \\
\hline & Educational background & & & & \\
\hline & SD (elementary) & 6 & 20.0 & 0 & 0.0 \\
\hline & SMP (junior high) & 13 & 43.3 & 8 & 26.7 \\
\hline \multirow{3}{*}{3} & SMA (senior high) & 11 & 36.7 & 22 & 73.3 \\
\hline & Job & & & & \\
\hline & IRT (Housewive) & 27 & 90.0 & 30 & 100. \\
\hline \multirow[t]{5}{*}{4} & Self employed & 3 & 10.0 & 0 & 0.0 \\
\hline & Paritas & & & & \\
\hline & multiparous & 22 & 73.3 & 18 & 60.0 \\
\hline & Primapra & 6 & 20.0 & 12 & 40.0 \\
\hline & Grande & 2 & 6.7 & 0 & \\
\hline
\end{tabular}

Based on the table above, the majority of respondents aged between 20-35 years both in the treatment group $(73.3 \%)$ and in the control group $(70 \%)$. In fact, the respondent education in the majority treatment group was junior high $(43.3 \%)$ and in the control group, the majority was senior high school (73.3\%). Respondents' occupations were mostly not working or as housewives (IRT) in both the treatment group (90\%) and the control group (100\%). Most respondents in the control and treatment group were multiparous, namely $73.3 \%$ in the treatment group and $60 \%$ in the control group [7] said that labor is influenced by several predisposing factors, including parity, age, knowledge and education. Labor is influenced by several factors, namely age, parity, the distance of pregnancy, education, and mother's knowledge [8]. [9] in their results showed a significant relationship between age and parity with the length of labor as indicated by the p-value of 0.001 .

2. The length of the 1 st stage

Table 2. The length of the 1 st stage

\begin{tabular}{|c|c|c|c|c|c|c|c|}
\hline & \multicolumn{4}{|c|}{ The length of $1_{\text {st }}$ stage } & \multirow[b]{3}{*}{ pvalue } & \multirow[b]{3}{*}{ RR } & \multirow[b]{3}{*}{ CI } \\
\hline & \multicolumn{2}{|c|}{$<=6$ hours } & \multicolumn{2}{|c|}{$>6$ hours } & & & \\
\hline & $\mathrm{N}$ & $\%$ & $\mathrm{n}$ & $\%$ & & & \\
\hline Group & 30 & 100.0 & 0 & 0.0 & 0.002 & 1.36 & $\begin{array}{l}1.09 \\
- \\
1.69\end{array}$ \\
\hline
\end{tabular}

Treatment

$\begin{array}{lllll}\text { Control } & 22 & 73.3 & 8 & 26.7\end{array}$

Based on the table above, it can be seen the difference in the $1_{\text {st }}$ stage in the treatment group compared to the control group. This is indicated by the value of p-value 0.002 and RR 1.36.

Childbirth is a process that ends with the release of the results of the conception [10]. This process begins with labor contractions, which are characterized by progressive changes in the cervix (cervical dilatation) and end with placental birth [11]. Birth ball is a physical therapy ball that can help the mother who is in the first stage of labor to a position that is useful to help the progress of labor. This birth ball exercise can be started from pregnancy [4]. One of the movements in birth ball training is pelvic rocking, which is useful for increasing the pelvic area, pushing the baby's head down due to the force of gravity, and thus increasing the rate of labour [4].

Surtiningsih, et al (2016) [6] research shows that Pelvic Rocking Exercises are very effective in shortening the length of time in the first phase of active phase with a value of $\rho$-value of 0,0001 . Hassan Zaky, Nevertity (2016) [12] in his research mentioned that there were significant differences in the duration of the first stage of labor in the control group and the treatment group Birth ball training was given with a $\mathrm{p}$ value of 0,000

Tussey CM, et al (2015) [9] in the results of their study showed a significant difference between the duration of the first stage of labor in the control group and the treatment group was given birth balls. This exercise significantly increased the acceleration rate of stage 1 by 29 minutes compared to the control group.

Shirazi, et al (2019) [13] in the results of their study showed a significant difference in time 1 in the group receiving birth ball treatment during pregnancy with a p-value of 0.003 .

Normal childbirth is a labor that begins in time and without the provision of certain drugs [14]. Mirzakhani, et al (2014) [5] stated in their research that there were significant differences in the treatment group that received birth ball training with the type of labor faced compared to the control group. Most of the respondents, $92.60 \%$ of respondents gave birth by vaginal birth, and the rest gave birth by sectio caesaria caused by the first stage of $29.6 \%$.

Hau, et al (2012) [15] in their research showed that there was a significant difference in the duration of the first stage of labor in the treatment group undergoing birth ball training, with a p-value of 0.003 .

Research by Gau ML, et al (2011) [3] shows that birth ball training in the treatment group can shorten the length of the first stage of labor, reduce analgesic use, and reduce the incidence of labor by sectio caesaria.

3. The length of 2 nd stage

Tabel 3. The length of the 2nd stage

\begin{tabular}{|c|c|c|c|c|c|c|}
\hline \multicolumn{4}{|c|}{ The length of 2nd stage } & \multirow[b]{3}{*}{$\begin{array}{c}\text { pval } \\
\text { ue }\end{array}$} & \multirow[b]{3}{*}{ RR } & \multirow[b]{3}{*}{ CI } \\
\hline \multicolumn{2}{|c|}{$\begin{array}{c}\text { primi }<=1 \\
\text { hour and } \\
\text { multi }<1 / 2 \\
\text { hour }\end{array}$} & \multicolumn{2}{|c|}{$\begin{array}{r}\text { primi }>1 \\
\text { hour, and } \\
\text { multi }>1 / 2 \\
\text { hour }\end{array}$} & & & \\
\hline $\mathrm{n}$ & $\%$ & $\mathrm{n}$ & $\%$ & & & \\
\hline 28 & 93.3 & 2 & 6.7 & $\begin{array}{c}0.02 \\
0\end{array}$ & 1.33 & $\begin{array}{l}1.03 \\
1.71\end{array}$ \\
\hline 21 & 70.0 & 9 & 30.0 & & & \\
\hline
\end{tabular}

Based on the table above, the results of the study showed that there was a significant difference in the second stage between the treatment groups with the 
[3] Gau M-L, Chang C-Y, Tian S-H, Lin K-C. Effects of birth ball exercise on pain and self-efficacy during childbirth: a randomised controlled trial in Taiwan. Midwifery. 2011 Dec;27(6):e293-300. Availablefrom:

[4] Aprilia, Yessie, Gentle Birth Melahirkan nyaman tanpa rasa sakit. Jakarta : Gramedia Widiasarana Indonesia, 2011.

[5] Mirzakani, Kobra,et al, The effect of birth ball exercise during pregnancy on mode delivery in primiparous women. Journal of Midwivery and Reproductive Health, 2014.

[6] Surtiningsih, Kun Aristiati Susiloretni, Sri Wahyuni, Efektivitas Pelvic Rocking

Exercises terhadap Lama Waktu

Persalinan pada Ibu primiparous di

Puskesmas Wilayah Kabupaten

Banjarnegara. Jurnal Keperawatan Soedirman (The Soedirman Journal of Nursing), Volume 11, No.2, Juli 2016.

[7] Sarwono, Buku Acuan Nasional Pelayanan Maternal dan Neonatal. Jakarta: PT. Bina Pustaka, 2009.

[8] Walsh LV, Buku Ajar Asuhan Kebidanan Komunitas. Jakarta: EGC, 2007.

[9] Tussey, CM, et al, Reducing Length of Labour and Cesarean Surgery Rate Using a Peanut Ball for Women Labouring

With an Epidural.The Journal of Perinatal Education | Winter 2015, Volume 24, Number 1, 2015.

[10] Azwar, Asuhan Persalinan Normal. Jakarta : $\quad$ Depkes RI, 2008. respondents aged between 20-35 years old, high school educated, not working/housewife (IRT) and multi para. There was a significant difference in the duration of the [11] first and second stages of labor in the treatment group with birth ball exercises compared to the control group.

\section{ACKNOWLEDGEMENT}

Thank you to RISTEKDIKTI for funding this PDP research grant, Muhammadiyah Health Sciences institute of Gombong, which has provided moral and materials support, as well as the Central Health Care of Buluspesantren 1 and Adimulyo who have collaborated to be part of this research.

\section{BIBLIOGRAPHY}

[1] Badan Pusat Stastistik, Survey Penduduk antar Sensus (SUPAS). Jakarta: Badan Pusat Stastistik, 2015.

[2] Prawiroharjo, Ilmu Kebidanan. Jakarta : Bina Pustaka, 2009.
Varney H, Kriebs JM, Gegor CL. Buku Ajar Asuhan Kebidanan ,Ed.4 Vol 2. Jakarta: EGC, 2007.

Hassan Zaky, Nevertity, Effect of pelvic rocking exercise using sitting position on birth ball during the first stage of labour on its progress. IOSR Journal of Nursing and Health Science (IOSR-JNHS) e-ISSN: 2320-1959.p- ISSN: 2320-1940 Volume 5, Issue 4 Ver. III (Jul. - Aug. 2016), PP 19-27 www.iosrjournals.org. 2016.

Shirazi, et al, Experience of Childbirth With Birth Ball: A Randomized Controlled Trial. International Journal of Women's Health and Reproduction Sciences Vol. 7, No. 3, July 2019, 301-305 http://www.ijwhr.net doi 10.15296/ijwhr.2019.50 ISSN 2330-4456. 2019. 
[14] IBI, Konsep Persalinan Normal. article.https://www.ibi.or.id/en/article_view/A 20150117018/konsep-persalinan-normal.html, 2018.

[15] Hau, W L, Tsang, S L and Cheung, H Y, The use of Birth Ball as a Method of Pain Management Labour. Hongkong : Gynaecol Obstetri, 2012. pp. 63-68. Vol. 12, 2012.

[16] Depkes RI, Buku Acuan Pelatihan Klinik Asu han Persalinan Normal.Jaringan Nasional Pelatihan Klinik-Kesehatan Reproduksi. Jakarta : JNP K-KR, 2008. 